\title{
DURANTE MUITO TEMPO FOMOS DORMIR CEDO: Proust, BARTHES E MÁrlo CLÁdDIO CONTRA SAINTE-BEuVE
}

FOR A LONG TIME, WE USED TO GO TO BED EARLY: PROUST, BARTHES AND MÁRIO CLÁUDIO AGAINST SAINTE-BEUVE

http://dx.doi.org/10.11606/issn.2175-3180.v12i23p185-202

Gustavo Listo Pereira ${ }^{\mathrm{I}}$

\section{RESUMO}

Neste artigo, partimos das reflexões que Barthes desenvolveu em "Durante muito tempo fui dormir cedo" para analisar algumas peculiaridades das vozes narrativas presentes no romance Gémeos, de Mário Cláudio. Com isso, tentamos, por um lado, evidenciar possíveis aproximações entre o livro do romancista português e a obra de Proust e, por outro, demonstrar que Gémeos pode ser lido como um texto que efetua um desvio na lógica ilusória da biografia - lógica esta que não apenas faz parte de muitas biografias e romances biográficos mais tradicionais, mas que também é pressuposta pelo biografismo, o método crítico de Sainte-Beuve criticado por Proust. Em nossa análise, procuramos mostrar também a pertinência do conceito de terceira forma de Barthes para a compreensão de algumas especificidades da tessitura do romance de Mário Cláudio. Guiados por esse objetivo, aplicamos o conceito à leitura de Gémeos e, com isso, buscamos indicar mais claramente que o romance de Mário Cláudio é uma obra que, assim como Em Busca do Tempo Perdido, investe em uma escrita que promove uma fissura nos limites entre o narrar e o argumentar.

\section{PALAVRAS-CHAVE}

Mário Cláudio; Gémeos; Narrativa portuguesa contemporânea; Roland Barthes; Marcel Proust.

\section{ABSTRACT}

This article, based on Barthes's reflections on "For a long time I used to go to bed early", analyzes some peculiarities of the narrative voices present in the novel Gémeos, by Mário Cláudio. On the one hand, it attempts to demonstrate possible similarities between the Portuguese novelist's book and the work of Proust. In contrast, it argues that Gémeos can be read as a text that steers away from the illusory logic of biographies - the same logic that is not only part of many traditional biographies and biographical novels, but is also assumed by biographisme, Sainte-Beuve's critical method that was also criticized by Proust. Furthermore, the analysis includes an effort to demonstrate the relevance of Barthes's concept of the third form for the understanding of some specificities of Mário Cláudio's novel, in order to establish that it has the type of writing that, similarly to In Search of Lost Time, it fractures the limits between narration and argumentation.

\section{KEYWORDS}

Mário Cláudio; Gémeos; Contemporary Portuguese narrative; Roland Barthes; Marcel Proust.

\footnotetext{
I Universidade Federal Fluminense, Niterói, Brasil.
} 
Em 1978, no Collège de France, Roland Barthes apresentou ao público uma conferência cujo título tinha sido retirado da cena inicial de La Recherche du Temps Perdu: "Durante muito tempo, fui dormir cedo". Sua palestra, que depois iria se transformar em um dos artigos do livro O rumor da língua (BARTHES, 1988), versou, como era de se esperar, sobre Marcel Proust. Foi com a argúcia que lhe era característica que Barthes, então, debruçou-se sobre certos aspectos da vida e da obra do grande escritor francês do século XX, contribuindo, assim, para iluminar o percurso dos leitores que se aventurassem pelas muitas páginas de Em Busca do Tempo Perdido.

Uma vez que proferiu um discurso dessa natureza na instituição em que dava aulas, podemos afirmar, com certa segurança, que Barthes tinha a clara intenção de dar sua colaboração para o acervo crítico de Proust. É possível supor também que o estudioso talvez tivesse a expectativa de que sua palestra atingisse uma dimensão mais ampla, ultrapassando os limites da Busca proustiana. Isso bem poderia fazer parte do horizonte de desejos de Barthes, afinal, ele era um intelectual de largo alcance, que enveredava por diversos sistemas sígnicos, passando por campos tão diversos quanto os da literatura, das imagens, da moda, dentre outros.

Além disso, se nos lembrarmos de que Barthes foi um crítico literário que não apenas produzia crítica, mas que também se preocupava bastante em interrogar o próprio papel da crítica que produzia; e se nos recordarmos ainda de que ele foi o responsável pela morte do autor e que, depois do "assassinato", tornou a investigar o texto como espaço de manifestação do sujeito, dessa vez em novos termos; enfim, se tivermos um panorama de sua trajetória de pesquisa em mente, então, poderemos até especular que Barthes, naquelas reflexões, utilizou Proust como uma espécie de tema disparador para enunciar um discurso que, no fundo, tratava também da literatura como um todo e, muito provavelmente, até de si mesmo.

Ainda que todas essas especulações sejam possíveis a partir do legado intelectual construído pelo crítico, o fato é que nunca saberemos ao certo se Barthes tinha o anseio de que seu texto transcendesse os contornos do âmbito da obra proustiana. De todo o modo, neste caso, nossa ignorância pouco importa, pois, tendo ou não tendo essa intenção, o crítico, naquela conferência, proferiu de fato palavras que, além de serem valiosas 
por lançarem luz sobre a escrita de Proust, também se tornaram profícuas para além da Busca. E é justamente essa amplitude das ideias difundidas por Barthes em "Durante muito tempo, fui dormir cedo" que procuramos demonstrar neste artigo.

Para alcançar esse objetivo mais geral, escolhemos apontar especificamente de que forma as considerações deixadas pelo crítico nos auxiliam a pensar sobre o livro Gémeos (2004), que é o objeto da pesquisa que ora desenvolvemos. Se tivermos sucesso em mostrar que as reflexões sobre Proust tecidas por Barthes, naquela ocasião, são capazes também de abrir caminhos para a leitura da obra de Mário Cláudio - um romancista português que tinha começado a publicar seus livros apenas quatro anos antes daquela conferência de 1978 -, então poderemos dizer também que o trabalho do crítico francês teve consequências imprevistas até para ele mesmo.

Estar diante de um fato inesperado como esse é, para nós, sempre interessante, pois ele faz com que vejamos que a crítica literária, apesar de parecer uma tarefa solitária e com vistas a um acabamento que se concretiza em um texto, é, em vez disso, um movimento criativo, feito por múltiplas vozes a dialogar, e que ela, como a utopia, pode levar a nossa compreensão para além do lugar onde nos acomodamos.

Dito isso, vejamos em primeiro lugar quais são as observações de Barthes a respeito da obra de Marcel Proust, para, em seguida, tratarmos do romance de Mário Cláudio, que é aqui o foco do nosso interesse mais específico.

Barthes inicia a primeira parte de seu artigo nos transportando para um momento importante da existência de Proust. Segundo ele, o escritor da Recherche, aproximadamente no ano de 1909, vivia um impasse. Na época, Proust desejava escrever uma obra, mas estava indeciso quanto à forma de sua escrita; deveria seguir pelas veredas do ensaio ou do romance? Seu esforço se concentraria na interpretação, na defesa de uma tese, ou na construção de uma narrativa?

Inicialmente, o escritor parece ter escolhido a primeira opção, pois decidiu redigir um ensaio contra o então prestigiado método crítico de Sainte-Beuve. Entretanto, durante o processo de produção desse texto ensaístico, o projeto inicial foi sendo modificado. Primeiro surgiu em Proust a ideia de abordar o tema a partir da construção de um diálogo ficcional entre ele e sua mãe. Em seguida, o que era um ensaio se transformou em uma espécie de obra híbrida, que ele chamou de Contre 
Sainte-Beuve. Souvenirs d'une matinée, "um verdadeiro romance, e um romance extremamente impudico em certas partes" (PROUST apud CLARAC, 1988, p. 31). Por último, após abandonar de vez o plano de escrever sobre Sainte-Beuve, Proust se dedicaria finalmente a escrever o monumental Em Busca do tempo perdido.

Apesar de ter escolhido definitivamente a narrativa, Proust não abandonou totalmente o ensaio, já que a arquitetura da Busca, conforme nos aponta Barthes (1988, p. 285), corresponde a uma terceira forma, isto é, a uma estrutura original, nem de romance, nem de ensaio, mas dos dois ao mesmo tempo. Essa originalidade da estrutura da Busca, para Barthes, é instaurada logo na primeira cena da obra. A passagem é conhecida, mostra-nos o protagonista se revirando na cama entre a vigília e o sono e inicia-se pela frase que intitula a conferência: "Durante muito tempo, fui dormir cedo".

Na opinião do crítico, esse trecho de abertura da Busca, no qual o protagonista se encontra em um estado de "meia-vigília", estabelece, no fio do discurso da obra, "uma lógica da Vacilação" (BARTHES, 1988, p. 286). Essa lógica, diferentemente da "lei ancestral da Narrativa ou do Raciocínio" (BARTHES, 1988, p. 287), não está presa às amarras tradicionais da cronologia; por esse motivo, ela permite que a obra seja constituída por sequências discursivas formadas, ao mesmo tempo, por fragmentos intelectuais e narrativos. Em outras palavras, essa outra lógica inaugurada na cena inicial do livro possibilita que a obra literária se construa em uma terceira forma, ou seja, em uma estrutura que elimina a “contradição entre o Ensaio e o Romance" (BARTHES, 1988, p. 289).

Mas essa lógica fundada na primeira passagem da Busca não permite apenas a coexistência da narração e do ensaio crítico no universo ficcional da escrita proustiana. De acordo com Barthes (1988, p. 287), “o princípio da vacilação" também é responsável por desorganizar a "lógica ilusória da biografia", fazendo com que os elementos biográficos de Proust presentes na Busca sejam desviados. Dois desses grandes desvios assinalados na conferência de Barthes são os que atingem a pessoa enunciadora e a narrativa. Vejamos cada um deles separadamente.

O primeiro desvio apontado por Barthes se relaciona à pessoa que narra o romance e pode ser resumido da seguinte maneira: o narrador da $B u s c a$, essa figura que é posta em cena na obra literária, não corresponde exatamente à figura civil do autor. 
Essa tese de Barthes, como ele faz questão de reconhecer, aproximase da tese que Proust defendeu em seu inacabado ensaio Contre SainteBeuve $^{1}$. Segundo o escritor da Recherche, o procedimento de Sainte-Beuve, que consistia "em não separar o homem da obra, [...] em munir-se de todas as informações possíveis sobre um dado escritor" (PROUST, 1988, p. 51) com a finalidade de avaliar sua literatura, estava equivocado. O problema desse método, para Proust (1988, p. 51-52), é que ele desconhece que "um livro é o produto de um outro eu e não daquele que manifestamos [...] na sociedade". Esse outro eu, responsável pela obra literária na tese proustiana, é, na leitura de Barthes, o sujeito da enunciação que, na Busca, é representado pelo narrador e que não se identifica com o autor Marcel Proust.

É importante destacar que, hoje, no âmbito dos estudos literários, essa separação entre o narrador e o autor da Busca sublinhada pela análise de Barthes não constitui mais uma novidade. Sabe-se atualmente que em qualquer obra literária - e não apenas no romance proustiano - autor e narrador são entes diferentes. Mesmo assim, as considerações de Barthes são pertinentes, pois, ao retomarem o Contre Sainte-Beuve, elas nos mostram que Proust, diferentemente de muitos contemporâneos seus, tinha a convicção estética de que a obra não pode ser explicada pela vida, ou seja, de que há uma distância insuperável entre a existência de um indivíduo e a representação que ele constrói do mundo e de si mesmo dentro do romance.

O segundo elemento biográfico de Proust, que é desviado na Busca, de acordo com Barthes, é a narrativa. Sem dúvida, o relato que Proust escreveu possui um teor biográfico, porém, essa narração não corresponde à história da vida do autor. Em outras palavras, a Recherche não é uma espécie de biografia de Proust, nem mesmo uma biografia romanceada ${ }^{2}$. A

\footnotetext{
${ }^{1}$ É possível discutir se há diferenças entre a teoria de Barthes e a de Proust, mas o debate dessa questão não caberia nos limites deste artigo.

${ }^{2}$ Com o termo biografia romanceada, referimo-nos a obras narrativas que contam, por meio de recursos tipicamente literários, os fatos que marcaram a história da vida de uma pessoa que comprovadamente existiu; é o caso, por exemplo, do livro Frida Khalo, escrito por Rauda Jamis (2015). O termo se distingue da biografia pura e simples, obra que também narra eventos ocorridos durante a existência de um indivíduo não ficcional, mas que não apresenta elementos característicos da narração romanesca, tais como, entre outros, a construção de diálogos inventados, a presença de narradores que revelam um ponto de vista subjetivo e a incorporação de personagens e situações à narrativa que, muitas vezes, não podem ser comprovados por documentos. Sabemos que a distinção entre biografia e biografia romanceada não é simples e que atualmente se pode entender que "a projeção do biógrafo em sua escrita é tamanha que as fronteiras se tornaram indistintas entre biografia e autobiografia, como também entre fato e ficção [...]." (DOSSE, 2015, p. 6). Apesar disso, optamos por utilizar os dois termos, pois eles nos ajudam a compreender as especificidades da Busca e, sobretudo, de Gémeos.
} 
forma biográfica do romance, destaca Barthes (1988, p. 288), é desviada; ela não se assemelha à estrutura das narrativas biográficas mais tradicionais, que costumam atravessar linearmente os anos do protagonista. A ausência dessa estratégia da linearidade temporal, desse mecanismo característico das biografias, ficcionais ou não ficcionais, demonstra, na visão de Barthes (1988, p. 288), que não é a vida de Proust que é contada na Busca, mas o seu desejo de escrever.

Apesar de ser bastante plausível, essa leitura, assim como o fascismo da língua destacado em Aula (2004) e muitas outras reflexões que Barthes felizmente nos deixou, é bastante polêmica. Que a Busca não narra exatamente a vida de Proust, nós sabemos, mesmo porque a obra é ficcional. Quanto à questão do desejo, talvez seja mais interessante pensar que a ambição da escrita une Proust ao protagonista de forma mais evidente do que os eventos que compõem a existência dos dois. Nesse sentido, o desejo pode ser interpretado como o que há de mais biográfico na Busca.

De todo modo, ainda que a visão de Barthes nesse ponto seja controversa, ele nos mostra sua perspicácia ao indicar que o romance de teor biográfico redigido por Proust não é "feito segundo as ideias de Sainte-Beuve" (BARTHES, 1988, p. 285). Embora Proust tenha abandonado o ensaio para escrever a Busca, o autor não deixou de lado o seu combate às ideias do crítico literário do século XIX, porque o romance biográfico ${ }^{3}$ proustiano, pela forma como foi construído, vai de encontro ao conceito cartesiano de sujeito, que está implícito nas ficções narradas linearmente em primeira pessoa.

Isso pode ser vislumbrado em todas as experiências de memória involuntária no fio do discurso da Busca, que representam um indivíduo cindido, sujeito à ativação do inconsciente por meio das sensações. Esse personagem que "retorna continuamente à sua própria vida, não como a um curriculum vitae, mas como a uma constelação de circunstâncias e de figuras" (BARTHES, 1988, p. 288), corresponde a um ser humano desprovido do controle total sobre si, diferentemente do indivíduo que, na visão do método de Sainte-Beuve, era capaz de recuperar e de depositar conscientemente suas experiências de vida no texto literário. Portanto, ao escrever Em busca do tempo perdido, Proust encontrou uma maneira de

\footnotetext{
${ }^{3}$ Entenda-se, aqui, romance biográfico como uma obra literária que, apesar de narrar eventos ocorridos com personagens, ou seja, com indivíduos criados pela ficção, apresenta um laço muito estreito com a realidade, particularmente com os fatos que ocorreram durante a vida do autor.
} 
construir uma narrativa de caráter biográfico sem abrir mão de exercer sua crítica ao biografismo de Sainte-Beuve.

Agora que já esboçamos as principais ideias de Barthes sobre Proust, podemos passar para a segunda etapa deste artigo, na qual analisaremos o romance Gémeos a partir das reflexões do crítico sobre a Busca. Tal como Barthes fez em sua conferência no Collège de France, percorreremos principalmente dois pontos: o primeiro deles se relaciona à desorganização da lógica biográfica, tema que, como vimos, envolve o narrador e a narrativa; o segundo tem a ver com a terceira forma, ou seja, com o fato de que uma obra literária pode produzir um discurso que une o romanesco ao ensaístico.

Conforme apontamos anteriormente, para Barthes, a Busca, "obravida" de Proust, é constituída por um princípio que desorganiza a lógica biográfica. Isso significa que os elementos biográficos de Proust são, no romance, desviados. Dentre esses elementos estão a pessoa enunciadora, que, na Busca, não é Marcel Proust, e a narrativa, que, no romance, não corresponde à história da vida do autor. Gémeos, por sua vez, também pode ser lido como um romance de caráter biográfico, mas, nele, o desvio da lógica biográfica parece ser um pouco mais complexo do que na obra de Proust, pois o livro escrito por Mário Cláudio possui três instâncias enunciadoras separadas nitidamente por capítulos diferentes.

A voz narrativa que ocupa a maior parte do romance é certamente a de Dom Francisco, personagem que, sem dúvida alguma, representa o pintor Francisco de Goya (1746-1828). Presente nos capítulos mais longos do livro, esse narrador conta a história de sua vida, particularmente o período em que ele, estando já na terceira idade, se exilou em sua Quinta del Sordo, uma propriedade rural nos arredores de Madri.

Ali instalado, o decrépito Dom Francisco, vítima dos pesadelos e das enfermidades, apresenta-nos sua versão sobre os conflitos travados com Leocádia e com Rosarito, respectivamente, sua companheira e sua enteada. Entre os relatos dos seus problemas de saúde e dos embates com aqueles que o cercam, Dom Francisco faz menção à sua produção pictórica mais recente, a série de Pinturas Negras. A cena a seguir é um exemplo de como esses temas aparecem intrincados em sua narração:

Decorreram duas semanas, prossegui nos empastes daquele Saturno que me assombrava os dias. Ampliava-se o velho, louco como nunca, por dentro de mim e para além do meu inferno. Mas não tirava a ideia 
de Rosarito, nem dos passeios que os aguaceiros de resto não permitiam. Arredada da minha presença, andaria a miúda por certo magicando outras empresas, estabelecendo com as sabidas cozinheiras da casa confabulações em que se principiava a dissertar sobre os mistérios menstruais. E eu dilacerava-me de saudade, incapaz de descansar na horazinha da sesta. (CLÁUDIO, 2004, p. 39)

No trecho, Dom Francisco trabalha no seu famoso Saturno ${ }^{4}$. É interessante notar que, nessa etapa da vida, o artista pinta não um integrante da família real ou um evento cultural da Espanha de sua época, mas uma figura que o persegue como uma assombração: o deus mitológico do tempo. A pintura, portanto, surge em resposta a uma aflição psicológica; ela é uma atividade que busca a catarse. Contudo, não é apenas o Saturno que causa angústia no pintor; a ausência de Rosarito, personagem que, ao contrário do artista, vive em plena puberdade, também é sentida profundamente. Quem vai nos esclarecer qual é a relação da imagem com a menina não é, como veremos, o narrador em primeira pessoa, mas uma outra voz que se segue à dele.

Durante o livro todo, os capítulos que contêm a narração veiculada pelo personagem de Dom Francisco se alternam com outros constituídos por uma narração efetuada em terceira pessoa. Essa narração em terceira pessoa, por sua vez, se divide em duas; em certas partes, ela se detém sobre o mesmo assunto que a voz de Dom Francisco, em outras, no entanto, não.

A fim de diferenciarmos esses dois narradores em terceira pessoa, chamaremos o primeiro de narrador de Goya, pois, como foi dito, ele narra acontecimentos que dizem respeito ao personagem do pintor, ou seja, relata os embates entre os habitantes da quinta e o processo de criação de Dom Francisco. Anteriormente, vimos a passagem em que o narrador em primeira pessoa menciona a famosa pintura do Saturno. Vejamos agora como essa imagem pictórica aparece nas palavras do narrador de Goya:

Haveria ele de decidir a partir daí que importava pôr cobro ao lúgubre fatalismo com que vão devorando os filhos a vida dos progenitores. $\mathrm{E}$ odiava essa lei que a Natureza lhe impunha, e parecia-lhe ela obscura e horripilante como se devesse cada ninhada de láparos esventrar a coelha que os amamentara. Mais conforme a uma norma de harmonia,

\footnotetext{
4 Saturno é uma famosa pintura criada por Goya entre 1820 e 1823. Trata-se de um óleo que foi transferido do mural da Quinta del Sordo para uma tela, com 143,5 cm x 81,4 cm de tamanho. Atualmente o quadro se encontra no Museo Nacional del Prado, em Madri. Ver as referências on-line para ter acesso à imagem na página oficial da instituição (MUSEO NACIONAL DEL PRADO, 2019a e 2019b).
} 
decorrendo do respeito que merece quem concede a existência, e que portanto guarda o direito de a retirar, afigurava-se-lhe o destino do pai do Tempo, ascendendo nu de uma gruta de térreas humidades, esburgando num festim de gigantesco pavor as carnes das crias que engendrara. E diante de Rosarito muito mais tarde, sofrendo o irresistível ímpeto com que se ia evadindo a menina do cárcere a que a condenara, erguera-se-lhe de súbito, a flanquear uma das portas do piso inferior da casa da Quinta, a envergadura de Saturno omnipotente.

O velho deus escancarava os olhos sanguinolentos, e toda a monstruosidade do Planeta se quedava neles reflectida. E apertava entre os dedos o corpo hirto de Rosarito, pronto a esquartejá-la antes de a levar à boca, impedindo-a de conceber os que a votassem a uma sorte igual, ínfimos números da eterna procissão dos que nascem para matar, produzindo aqueles que na sua hora haverão de os assassinar também, de tudo não restando mais do que o amarelado sulco de soro e de pus. (CLÁUDIO, 2004, p. 44-45)

Dentro do contexto do romance, a cena acima vem logo após o relato da visita que Goya faz à sua terra natal depois de ser alçado em Madrid à posição de pintor da realeza. Ao retornar à casa de sua infância, o artista, por causa do status social adquirido na capital do país, é recebido por sua mãe e pelas "mulheres domésticas" de maneira afetada. Elas, por se acharem em condição inferior, não se sentam à mesa ao lado do pintor e procuram agradá-lo durante as refeições, oferecendo-lhe uma série de alimentos.

Segundo o narrador de Goya no primeiro parágrafo citado, Dom Francisco, desde essa ocasião, dá-se conta da existência do princípio quase inexorável que faz com que o crescimento dos filhos seja pago com o envelhecimento dos pais. A imagem de Saturno - deus do tempo que, devorando seus filhos, inverte a lógica à qual os progenitores estão condenados - teria surgido, de acordo com o relato do narrador em terceira pessoa, a partir dessa reflexão do pintor.

Anos depois, em sua velhice, Dom Francisco, motivado pelo sofrimento advindo da observação do amadurecimento de Rosarito e dos fatos que se dão na puberdade da menina, finalmente, materializa, nas paredes de sua casa, os contornos da representação visual que lhe havia sido inspirada por ocasião da visita à mãe. Portanto, assim como no discurso do narrador em primeira pessoa, a atividade pictórica surge como 
uma maneira de Dom Francisco alcançar a catarse, de sublimar as angústias e os desejos represados na velhice.

Esses dois relatos, o do retorno de Dom Francisco à casa materna e o do momento em que a pintura do Saturno é estampada pelo pintor nas paredes da Quinta del sordo, são apenas alguns exemplos das narrações efetuadas pelo narrador de Goya. No entanto, eles nos mostram que esse narrador em terceira pessoa acompanha a história que é contada nos capítulos nos quais Dom Francisco assume o posto de narrador. Além disso, os relatos também evidenciam que esse narrador, diferentemente da voz em primeira pessoa, é caracterizado pela onisciência. Até aí, nenhuma novidade; entretanto, se observarmos o segundo parágrafo do trecho supracitado, podemos perceber um dado bastante interessante.

Nessa parte específica, o narrador de Goya passa a adotar outra estratégia. Ele permanece narrando, mas que história ele nos conta? O caso do velho deus Saturno sanguinolento que apertou o corpo de Rosarito, esquartejando-o antes de ingeri-lo. Evidentemente, essa cena não pertence à narrativa que vinha sendo contada; ela se destaca, ou, para usar as palavras de Barthes, desvia-se dos relatos anteriores.

Aqui, temos um exemplo claro de terceira forma. Nesse trecho, o narrador onisciente faz uma leitura da imagem produzida por Goya a partir dos elementos biográficos do pintor. Trata-se de um discurso que, embora seja narrativo, assemelha-se ao do ensaio, já que nele há também descrição - sobretudo dos olhos de Saturno - e interpretação. Portanto, o narrador de Goya não apenas é responsável por acompanhar e acrescentar dados ao relato do narrador em primeira pessoa; ele se soma à voz de Dom Francisco para analisar as composições do pintor por meio de narrativas ensaísticas que relacionam a vida à obra do pintor.

Com a análise da narração empreendida por Dom Francisco e pelo narrador de Goya, o leitor poderia pensar que Mário Cláudio escreveu, em Gémeos, uma espécie de obra que varia apenas entre a construção de uma espécie de autobiografia ficcional - escrita pelo personagem do pintor - e a elaboração de uma biografia romanceada - escrita pelo narrador em terceira pessoa.

No entanto, antes de chegarmos a essa conclusão, precisamos investigar todas as vozes do discurso e, conforme dissemos anteriormente, não encontramos, em Gémeos, apenas um narrador onisciente. No romance, há também outra voz em terceira pessoa, que surge em capítulos diferentes 
daqueles nos quais o narrador de Goya se manifesta. Vejamos a primeira cena em que ela aparece:

Estava ele pois naquele Verão encalhado na cidade peninsular, a fim de empreender, munido de um problemático subsídio de estudos, uma certa indagação sobre a fase última do pintor. Desde há anos que um arraigado enamoramento, alimentado pelas renascenças a que as várias vanguardas sujeitavam o trabalho dos anos terminais do artista, lhe fora tornando fatal a decisão de uma permanência. (CLÁUDIO, 2004, p. 11)

O fragmento citado corresponde exatamente ao início do romance. Nele, deparamo-nos com uma voz em terceira pessoa que não relata eventos relacionados à vida de Dom Francisco. Em vez de perseguir o caminho traçado pelo narrador de Goya ou pelo narrador em primeira pessoa, esse terceiro narrador nos conta a trajetória de um personagem anônimo que se estabelece na capital da Espanha com a pretensão de pesquisar e de escrever sobre a última fase da vida e da pintura do artista. Por causa desse percurso narrativo diferenciado, chamaremos essa voz de narrador do pesquisador.

O papel do narrador do pesquisador nos parece fundamental dentro da obra. Ao relatar a história do homem que, assim como o próprio escritor Mário Cláudio, debruça-se sobre a biografia e sobre a arte do pintor espanhol, o narrador do pesquisador evidencia o fato de que o tema principal do livro não é exatamente a vida de Goya; ele nos mostra que Gémeos não pode ser lido como uma biografia romanceada, isto é, como uma obra que, baseada em documentos, reconta literariamente as passagens relevantes da vida de um indivíduo ilustre.

Além disso, o narrador do pesquisador nos demonstra também que o romance não se constitui apenas por um discurso que simula uma autobiografia construída pelas próprias palavras do pintor. Nesse sentido, é possível dizer que o primeiro capítulo de Gémeos, assim como o episódio do sono na Busca, instaura uma espécie de princípio de vacilação que desarticula a lógica ilusória da biografia na obra. Entretanto, se, na Busca, a vacilação se relacionava aos elementos biográficos de Proust, em Gémeos, a vacilação é dupla porque desvia tanto os elementos biográficos de Goya quanto os elementos biográficos de Mário Cláudio.

Diz Barthes, citando Painter, que a Busca é uma "história simbólica da vida de Proust" (BARTHES, 1988, p. 288). Do mesmo modo, podemos 
afirmar que Gémeos contém uma narrativa que simboliza parte da existência de Mário Cláudio. Evidentemente, estamos diante de narrativas simbólicas e não de autobiografias; na Busca, como vimos, os elementos da vida de Proust são desviados, fazendo, em primeiro lugar, com que Marcel Proust não seja a pessoa enunciadora do romance e, em segundo, com que a narrativa não corresponda exatamente à história da existência do autor. A mesma vacilação biográfica, obviamente, atinge Gémeos; nesse romance contemporâneo, tanto o narrador do pesquisador quanto o narrador de Goyapessoas enunciadoras que se confundem com Mário Cláudio - não correspondem à voz do autor; do mesmo modo, a narrativa que o narrador do pesquisador conta não pode ser confundida, apesar da semelhança, com parte da história da vida do autor.

Nesse sentido, Gémeos é, de maneira semelhante à Busca, a expressão "de um sujeito absolutamente pessoal que retorna [...] à sua própria vida, não como a um curriculum vitae, mas como a uma constelação de circunstâncias e de figuras" (BARTHES, 1988, p. 288). Mário Cláudio transforma elementos de sua existência - a admiração pelo trabalho de Goya, o desejo de escrever uma obra sobre o pintor, os transtornos de ansiedade e de agorafobia - em matéria para a sua literatura. Seguindo os passos de Proust, o autor português percebeu que "não tinha de 'contar' sua vida, mas que a sua vida tinha entretanto a significação de uma obra de arte" (BARTHES, 1988, p. 288).

Mas não é apenas a vida de Mário Cláudio que, desviada, transforma-se em representação artística nas páginas de Gémeos. Os poucos elementos biográficos do derradeiro período da existência de Francisco de Goya sobre os quais temos notícia também adquirem, por meio do princípio da Vacilação, "a significação de uma obra de arte" (BARTHES, 1988, p. 288) no romance. Seguindo essa leitura, da mesma maneira que Proust não é o narrador da Recherche, Goya nunca é a pessoa enunciadora do romance, nem quando sua figura está representada no narrador em primeira pessoa, que pretende claramente simular a sua voz. Tampouco o que se conta na voz de Dom Francisco ou na voz do narrador de Goya corresponde exatamente àquilo que o artista teve de enfrentar ao final de sua existência na Quinta del sordo.

Isso significa que não é a história de Francisco José de Goya y Lucientes que está sendo contada em Gémeos. Na verdade, nunca poderemos saber com exatidão quais foram as circunstâncias pelas quais o 
pintor passou quando estava exilado; nunca saberemos qual era o teor de sua relação com Rosarito ou com Leocádia. Diante disso, como entender a obra literária produzida por Mário Cláudio?

Segundo nossa interpretação, Gémeos, da mesma forma como Barthes julgou a Busca, é um romance sobre o desejo de escrever ou, de maneira mais precisa, sobre a materialização do desejo de escrever que surge no homem que se instala em Madri a fim de pesquisar "os anos terminais do artista" (CLÁUDIO, 2004, p. 11). Lendo dessa maneira, consideramos que o pesquisador, alter ego de Mário Cláudio, está por trás de toda a arquitetura enunciativa da obra. Nesse sentido, ele é tratado como um "supranarrador", figura que cria todas as vozes que integram o romance - o narrador em primeira pessoa, que corresponde ao discurso de Dom Francisco e os narradores em terceira pessoa, que chamamos de narrador de Goya e de narrador do pesquisador.

Essa leitura, que parte do princípio de que as vozes da obra literária não são autônomas, parece possível na medida em que as três dicções narrativas apresentam flagrantes semelhanças. Sem dúvida, as vozes do romance se distinguem pela escolha da categoria gramatical de pessoa, já que o narrador de Dom Francisco utiliza a primeira do singular ao passo que o narrador de Goya e o narrador do pesquisador empregam a terceira. Porém, todas possuem um estilo de narrar bastante parecido. Tal semelhança pode ser verificada inclusive no emprego da língua, pois notase, nos três narradores, o gosto pelo reiterado uso de períodos longos e de orações subordinadas reduzidas, por exemplo.

Outro aspecto parece confirmar a nossa visão de que os narradores do romance estão vinculados ao personagem do pesquisador: a terceira forma. Vimos anteriormente como o discurso do narrador de Goya, durante o desenrolar do relato da produção do Saturno, une a forma ensaística à narração. Concluímos que, em determinado momento, o narrador em terceira pessoa abandona a história de Dom Francisco para fazer uma leitura da imagem produzida por Goya a partir dos elementos biográficos do pintor, inserindo, assim, Rosarito na pintura negra que tem como protagonista a figura do deus mitológico do tempo. Curiosamente, encontramos também, no discurso do narrador em primeira pessoa, esse processo que une o ensaio à narração. Vejamos um exemplo.

Uma das cenas contadas por Dom Francisco durante o romance é o trágico enforcamento do jardineiro Simón. Esse personagem, segundo o 
discurso narrado em primeira pessoa, aproximou-se do pintor durante os eventos da guerra contra Napoleão. Junto com Dom Francisco, Simón percorreu os espaços devastados pelo conflito bélico e avistou os cadáveres dos combatentes, muitos deles decepados e empalados. Dessa experiência terrível, o jardineiro colheu uma espécie de trauma que o perseguiria pelo resto da vida até o momento em que, abatido pela loucura, ele comete suicídio. O episódio no qual o pintor encontra o corpo de Simón é narrado da seguinte maneira:

Numa manhã de Abril, [...] veio Rosarito buscar-me, [...] tomando-me pela mão. Atravessei com a pequena o jardim do nosso amigo, e juro que se me afigurou aquele espaço estranhamente frio e solitário. [...] Empurrou Rosarito a porta da loja dos aprestos, e ficou a mirar-me com a concentração habitual da menina curiosíssima. Pendente de uma corda que passava por um gancho na trave-mestra, balouçava Simón inteiriço. Inclinava sobre o peito a cabeça de cabeleira hirsuta, e esticava os dedos da mão direita como se quisesse esbofetear-nos. Haviam-lhe caído entretanto as calças, mal presas pelo fio de sisal, até à altura dos tornozelos encardidos. (CLÁUDIO, 2004, p. 66-67)

Sem dúvida nenhuma, o trecho que relata o encontro do cadáver de Simón dialoga explicitamente com uma das obras desenhadas por Goya: a lâmina 36, intitulada Tampoco ${ }^{5}$, que pertence à série Los Desastres de la Guerra. Esse diálogo é perceptível porque, no centro da gravura desenhada por Goya, em primeiro plano, observamos o cadáver de um homem enforcado que, de modo idêntico à cena do romance, possui as calças arreadas. Sendo assim, no texto de Mário Cláudio, o personagem da imagem produzida originalmente por Goya se transforma em Simón.

Esse episódio é apenas um exemplo do modo como as obras de Goya são retomadas e convertidas em passagens da "vida" do personagem Dom Francisco. Em Gémeos, há várias outras histórias narradas em primeira pessoa que partem não dos episódios da existência de Goya como ocorre em biografias e em biografias ficcionais -, mas das obras que ele nos deixou. Podemos identificar, nesse mecanismo, uma espécie de terceira forma; nesse caso, a narração, por ser inevitavelmente elaborada a

\footnotetext{
${ }^{5}$ Los Desastres da Guerra é uma série de gravuras criada por Goya entre 1810 e 1814 . Atualmente, os moldes de metal usados para imprimir as imagens dessa série encontram-se no Museo Nacional del Prado, em Madri. A água-forte Tampoco, especificamente, possui $157 \mathrm{~mm}$ x $208 \mathrm{~mm}$ de tamanho. Ver as referências on-line para ter acesso à imagem na página oficial do museu (MUSEO NACIONAL DEL PRADO, 2019a e 2019b).
} 
partir de uma interpretação e de um deslocamento do trabalho pictórico original de Goya, possui também um caráter ensaístico.

Isso nos mostra, como já afirmamos, que não é a biografia de Goya que está sendo narrada em Gémeos, afinal, não sabemos se o jardineiro Simón existiu, tampouco se ele percorreu, junto do pintor, os espaços devastados pela guerra ${ }^{6}$. Quando abrimos as páginas de Gémeos, defrontamo-nos, na verdade, com um texto que transforma a obra de Goya em uma versão completamente ficcional de sua vida. Portanto, o que parece biografia romanceada, na realidade, é romance mesmo - um romance apropriadamente carregado nas tintas dos elementos pictóricos e finamente acabado por algumas pinceladas de elementos biográficos que se desviam.

Sendo assim, se o que é relatado em Gémeos não é exatamente a vida do pintor, mas sua obra transformada em ficção, então, a voz que narra, em primeira pessoa, e que se confunde com a do próprio Goya, não pode ser tomada como se fosse a de um enunciador do discurso de uma espécie de autobiografia ficcional. Seguindo o mesmo raciocínio, a voz que narra, em terceira pessoa, a história de Goya também não pode ser tratada como se fosse a instância de um discurso semelhante ao de uma biografia romanceada ou a de um romance biográfico.

Em Gémeos, o narrador Dom Francisco não corresponde a Francisco José de Goya y Lucientes, assim como o narrador em terceira pessoa não corresponde a voz de um biógrafo qualquer. Ambas são vozes romanescas criadas por um mesmo sujeito, que constrói ficção a partir de ensaio - como no episódio de Simón - e que constrói ensaio a partir de ficção - como na passagem em que Rosarito se transforma na vítima de Saturno. Esse indivíduo que cria um livro em terceira forma composto por três narradores está, aliás, representado na própria narrativa: trata-se do

\footnotetext{
${ }^{6}$ Essa possibilidade de o artista ter visto com os próprios olhos as cenas mais brutais das batalhas e de as ter registrado como uma espécie de correspondente de guerra é, aliás, muito remota. Como nos mostra Robert Hughes em seu completíssimo livro sobre Goya (HUGHES, 2007), o pintor já era sexagenário e já estava surdo quando a invasão napoleônica ocorreu em seu país. Portanto, apesar de o artista afirmar em algumas legendas de suas imagens de Los Desastres de la Guerra que ele mesmo presenciou aquelas cenas, sua condição de saúde frágil torna pouco crível a hipótese de que o artista pudesse escapar com vida da visualização dos combates in loco. De todo modo, para a arte, isso pouco importa; mesmo não estando presente, Goya “inventou uma espécie de ilusão a serviço da verdade" (HUGHES, 2007, p. 322). E Mário Cláudio, por sua vez, criou uma narrativa que, em vez de registrar o evento como uma biografia, ou seja, refutando a presença do pintor no campo de batalha, prefere reforçar a ficcionalidade dos títulos das gravuras. Isso inclusive serve para corroborar a ideia de que todos os relatos de Gémeos são, na verdade, criados por aquele pesquisador que, em vez de justificar a obra a partir dos elementos da vida, como Sainte-Beuve fazia, cria uma ficção a partir da ficcionalidade do trabalho pictórico de Goya.
} 
pesquisador, sujeito de linguagem que, perto do final do romance, começa "a escrever as primeiras páginas dos últimos tempos do pintor." (CLÁUDIO, 2004, p. 116)

Antes de chegar a tal ponto, quando enfim consegue desenvolver sua escrita, o pesquisador, assim como Dom Francisco e Simón, passa por um trauma psicológico. Essa experiência ocorre quando o personagem sobe as escadas e ingressa no Museu do Prado para estudar as imagens de Goya. Vejamos a cena:

Do plano térreo que correspondia ao da entrada principal até ao andar onde se poderiam alcançar as obras do seu pintor não mediaria mais do que uma quarentena de degraus, capazes de todavia lhe alterar por completo o rumo da existência, e muito especialmente o modo de a encarar. À sua frente, e num caos de linhas que se entrecruzavam e se desfaziam, mesclavam-se as cores dos quadros expostos, um rosto interrogativo, o acendo de um arvoredo, o derrube da bandeira de uma batalha, e nada pertencia a nada, e tudo aquilo que ele mentalmente fora lhe parecia ter chegado sem remissão ao termo. Era no pavor infrene que se debatia como num mar imenso, destituído de tábua de salvação, entregue ao furor que não lograva identificar senão como a catástrofe final do Universo criado. (CLÁUDIO, 2004, p. 41)

O distúrbio que se abate sobre o pesquisador surge no momento exato em que ele avista as imagens dentro do museu. Embora o trecho não seja muito específico em relação a quais composições estavam diante do personagem quando ele começa a se sentir mal, podemos supor que as telas de Goya, provavelmente, as pinturas negras, estão entre as que o levaram a desenvolver esse pavor quase patológico. Tal hipótese é reforçada, inclusive, pelo fato de que o narrador do pesquisador nos informa, em seu relato, que o próprio personagem atribui sua moléstia à "difusa energia do artista que viera estudar" (CLÁUDIO, 2004, p. 115). Dessa forma, o romance reforça a ideia de que a arte de Goya, sobretudo a que o pintor produziu no final de sua existência, é capaz de nos fazer entrar em contato com o lado mais cruel e sombrio da humanidade.

Contudo, após se defrontar inicialmente com o terror nas imagens de Goya, o pesquisador se recupera; o distúrbio, com o tempo, reduz-se "a uma etiqueta que [possui] o efeito de o reorganizar" (CLÁUDIO, 2004, p. 115). Percebemos, então, que a arte, no romance, não é tratada apenas como uma atividade que nos desestabiliza; ela é também vista como um fenômeno capaz de nos estruturar - ou de nos reestruturar. 
É verdade que o pesquisador, como nos sugere o romance, talvez nunca consiga se livrar totalmente dos tormentos internos revelados pelas pinturas do artista espanhol; no entanto, não é à toa que, na narrativa, o pesquisador começa a escrever logo depois de passar pela experiência da reorganização. Após permitir que ele alcance a catarse, a pintura $o$ impulsiona a produzir outra obra artística. E sobre qual tema o pesquisador escreve? Como vimos, não é exatamente sobre a vida de Goya. O personagem cria uma ficção composta por narradores em terceira e em primeira pessoa que nos mostram justamente um Goya pintando não apenas para superar os terrores vivenciados durante a guerra, mas também para sublimar seus desejos durante a velhice.

Dessa forma, Mário Cláudio segue os passos de Proust na luta contra os princípios de Sainte-Beuve. Na Busca, conforme vimos anteriormente com Barthes, temos um protagonista que, pelo seu modo de narrar, questiona a noção cartesiana de sujeito implícita no método empregado pelo crítico literário francês do século XIX. O narrador de Proust não deposita sua vida na obra; ele constrói um discurso narrativo a partir de sua memória, que muitas vezes é ativada por processos inconscientes.

Por sua vez, em Gémeos, ao contrário do que pode parecer, não encontramos um personagem que recupera e que conta a própria vida, pelo menos não no discurso do narrador em primeira pessoa nem no relato do narrador de Goya. No livro de Mário Cláudio, não é a vida do pintor que explica ou que dá sentido à obra do artista espanhol, como queria SainteBeuve. Pelo contrário. Em Gémeos, é o pesquisador que, construindo o discurso ficcional da vida do artista, dá sentido à obra do pintor.

\section{REFERÊNCIAS}

BARTHES, Roland. Aula. Trad. Leyla Perrone-Moisés. São Paulo: Cultrix, 2004.

BARTHES, Roland. "Durante muito tempo, fui dormir cedo". In: O rumor da língua. Trad. Mário Laranjeira. Prefácio de Leyla Perrone-Moisés. São Paulo: Brasiliense, 1988. 
CLARAC, Pierre. Introdução do editor francês. In: PROUST, Marcel. Contre Sainte-Beuve: notas sobre crítica e literatura. Trad. Haroldo Ramanzini. São Paulo: Iluminuras, 1988.

CLÁUDIO, Mário. Gémeos. Lisboa: Dom Quixote, 2004.

DOSSE, François. O Desafio Biográfico: escrever uma vida. Trad. Gilson César Cardoso de Souza. São Paulo: Editora da Universidade de São Paulo, 2015. HUGHES, Robert. Goya. Trad. Tuca Magalhães. São Paulo: Companhia das Letras, 2007.

PROUST, Marcel. Contre Sainte-Beuve: notas sobre crítica e literatura. Trad. Haroldo Ramanzini. São Paulo: Iluminuras, 1988.

RAUDA, Jamis. Frida Khalo. Trad. Luiz de Castro e Costa. São Paulo: Martins Fontes, 2015.

\section{REFERÊNCIAS ON-LINE}

MUSEO NACIONAL DEL PRADO, Goya dedicada à pintura Saturno. 2019. Disponível em: http://www.museodelprado.es/goya-en-elprado/obras/ficha/goya/saturno-devorando-a-un-

hijo/?tx_gbgonline_pi1\%5Bgocollectionids\%5D=6\&tx_gbgonline_pi1\%5B gosort $\% 5 \mathrm{D}=\mathrm{d}$. Acesso em 26 de out. de 2020.

MUSEO NACIONAL DEL PRADO, Goya dedicada a Tampoco, gravura 36 de Los Desastres de la Guerra. 2019. Disponível em: https://www.museodelprado.es/coleccion/obra-de-arte/tampoco/ ea76b5ed-b37d-4acc-ac95-e077d92e70bd. Acesso em 26 de out. de 2020.

Recebido em 28 de outubro de 2020

Aprovado em 10 de dezembro de 2020

Licença: (c) (7) (5)

Gustavo Listo Pereira

Graduação em Letras e Mestrando em Estudos de Literatura na Universidade Federal Fluminense.

Contato: gustavolisto@id.uff.br 